GLOSSARY

\title{
Housing standards: a glossary of housing and health
}

\author{
P Howden-Chapman
}

J Epidemiol Community Health 2004;58:162-168. doi: 10.1136/jech.2003.011569

This glossary has been designed to provide definitions that take account of different disciplinary and policy traditions and to consider the aspects of housing that provide scope for possible concerted research and action.

Every little habitation within the great foul nest of one high building - that is to say, the room or rooms within every door that opened on the general staircase-left its own heap of refuse on its own landing, besides flinging other refuse from its own windows. The uncontrollable and hopeless mass of decomposition so engendered, would have polluted the air, even if poverty and deprivation had not loaded it with their intangible impurities; the two bad sources combined made it almost insupportable. (Charles Dickens)'

Any common sense evaluation will tell us that causation in part goes from poor housing to bad moral, mental and physical health. (Gunnar Myrdal) ${ }^{2}$

We give shape to our buildings, and they in turn shape us. (Winston Churchill in a 1943 speech to the House of Commons).

1 n the 19th century, public health initiatives that focused on housing did so because of the terrifying rates of infectious diseases and the common concern that these were concentrated in tenement buildings, which were poorly constructed, rack-rented, and did not allow air and light to circulate. The miasma theory proposed that the resultant fetid, malodorous air led to diseases like malaria ("bad air") or through fermentation to zoonotic diseases and that these were the cause of sickness. ${ }^{3}$ These views only needed minor adjustment to encompass the later biological theory that it was the lurking bacteria that caused illness. Underlying these theories of causation was a moral view that what the feckless poor needed most to improve their housing and health was hygiene; they needed to be taught to clean their houses better and not to crowd together.

A few writers of the time adopted more radical views of the health consequences of housing. In the first clear case of multilevel analysis, Friedrich Engels used both mortality and municipal records to calculate the ratio of the living to the dead by categorising people not only by the ranking of the individual houses, from best to worst in the street, but also by the class of the street they lived in. The survival ratio was highest among those living in the best houses in the best streets. $^{4}$

These 19th century aetiological theories have their 21 st century counterparts. There are a number of aspects of housing that are understood to have a direct impact on health: the structure of housing; internal conditions such as damp, cold, and indoor contamination; and the behaviour of the occupants. ${ }^{5}$ Indirect housing effects related to housing tenure, including wealth impacts, and neighbourhood effects are seen as increasingly important.

Housing as a neglected site for public health action has been identified in a number of recent national reports. ${ }^{6-8}$ These reports highlight that indoor and outdoor housing conditions, as well as the material and social aspects of housing, and local neighbourhoods have an impact on the health of occupants. Moreover, systematic improvements in housing can improve health and reduce inequalities in health.

Housing and health research draws on research from a large number of disciplinary fields. This glossary has been designed to provide definitions that take account of different disciplinary and policy traditions and to consider the aspects of housing that provide scope for possible concerted research and action.

\section{THE PHYSICAL STRUCTURE OF HOUSING}

The physical structure of housing is an important part of the built environment. It encompasses both building materials and design, both of which can affect health. Examples of construction material impacts are: formaldehyde emissions from fibre-board materials; the release of asbestos from textured ceilings; and fibres from glass insulation material, which are all hazardous for human health. Particular designs create distinct problems of structural integrity, such as the apartments constructed from concrete, with inadequate steel reinforcing, in the former communist countries of Eastern Europe. Other design health effects include inadequate ventilation, and damp and mould.

\section{INDOOR ENVIRONMENT}

The indoor environment refers to the quality of air inside the dwelling-which can be contaminated from a number of different sources, principally from building materials; side effects of heating; moulds and environmental tobacco smoke. ${ }^{9}$ In dwellings located besides busy roads and intersections, outdoor air contaminants from motor vehicle exhaust can pollute the indoors by being sucked in through windows or air 
conditioning systems. Contaminants from work and waste sites can be tramped inside on footwear. All these factors may influence the development of disease, through inhalation or ingestion. In some areas radon is also a major problem. ${ }^{10}$

Indoor heating is a major contributor to the quality of the indoor environment by raising the indoor temperature and, in the case of open fires and unflued gas appliances, releasing particulates, which irritate the airways and may suppress immune functioning. ${ }^{11}$ The burning of fossil fuels in gas cookers and un-flued gas heaters generates nitrogen dioxide and sulphur dioxide. As a result of incomplete combustion a number of other harmful contaminants are produced (hydrocarbons, carbon monoxide and particulate matter from inorganic matter in the fuel). Liquid petroleum gas or natural gas is generally perceived to be cleaner, but the byproducts listed above can still be produced from incomplete combustion of these fuels. Environmental tobacco smoke from occupants' cigarettes also produces harmful particulates.

Exposure to nitrogen dioxide inflames airways and presents a small but significant excess risk to vulnerable populations, especially children. ${ }^{12}$ Several researchers have noted a connection between gas cooking and respiratory illness in children. ${ }^{13-15}$ There is evidence that exposure to nitrogen dioxide in the week before the start of a respiratory viral infection, and at levels within current UK standards, is associated with an increase in the severity of resulting asthma. ${ }^{16}$

\section{LEAD POISONING}

Increased blood lead concentrations in children, which affect their kidneys, reproductive organs, nervous system, and cognitive functioning have been linked to the ingestion of flaking lead paint in poorly maintained housing. ${ }^{17-20}$ Lead contaminated water from lead pipes is the other main source of lead intake in older homes. ${ }^{21}$ Recognition and regulation have led to an abatement of this problem, so that blood lead concentrations in children have declined dramatically, ${ }^{22}$ although there are still areas where children are at high risk. ${ }^{23}$

\section{DAMP AND MOULD}

Dampness in houses can be caused by the location of the house, structural defects in the house construction or maintenance, and the behaviour of the occupants, such as not airing the house by opening windows or using extractor fans during showering and cooking. Un-flued gas appliances also release water vapour that can increase the relative humidity in the house and lead to excess moisture in the building. ${ }^{24-28}$ Both subjective and objective measures of dampness in houses are used in research, and criteria are being established for evaluating observations in relation to exposure and adverse health effects, but it can be assumed that an estimate of the size of moisture damage is a reasonable surrogate for the exposure. ${ }^{29}$ Damp housing is clearly related to respiratory conditions in both adults and children. $^{25}{ }^{30-33}$

Mould is more likely to grow in damp houses and is usually measured by the size of the visible mould patches, or the mass of active colonies. ${ }^{34}$ A mouldy smell is a good indication of mould activity. Mould and fungi have been shown to have a small, but significant respiratory effect on children. ${ }^{35-40}$ There is a dose-dependent risk increase of visible mould for respiratory infections, lower respiratory symptoms, ${ }^{29}$ and asthma. ${ }^{33}$ There have also been isolated cases of mycotoxins producing haemorrhagic effect in children. ${ }^{41}$ Other biological products are $\beta$ glucins and endotoxins. ${ }^{42-44}$ It is not yet clearly known which micro-organisms, among the many species infecting moisture damaged materials in the home, are most important for causing ill health and disease..$^{45}$ Dust mites, which are the major producers of domestic allergens that exacerbate asthma, also thrive in damp housing. ${ }^{46-48}$

\section{COLD AND SEASONAL DIFFERENCES}

The temperature of the indoor environment affects the health of occupants. The WHO recommends that indoor house temperatures be no lower than $18^{\circ}$ and $20^{\circ}$ for the very old and very young. ${ }^{49}$ There is strong evidence that there is a narrow comfort zone for humans with mortality rates lower on days in which the average temperatures range between $15^{\circ}$ to $25^{\circ}$ and rising progressively as the ambient temperature becomes hotter or colder. Below these moderate temperatures there is some evidence that cold is a risk factor in increasing asthma severity and COPD and may also delay recovery after discharge from hospital..$^{50-56}$

Seasonal differences in temperatures have a greater impact on avoidable mortality in winter in temperate countries than in colder countries, where houses are more thermally efficient and outdoor clothing is worn more systematically. ${ }^{57-61}$ In Great Britain, for example, it is estimated that 40000 extra winter deaths occur each year because of housing and deprivation. ${ }^{99}$ In Great Britain an "inverse housing law" has been shown-those areas where climate is colder tend to be those where housing is worse. This maldistribution of good housing creates an additional environmental risk for those people living in colder areas for long periods of time and is associated with poorer respiratory health and diastolic hypertension. ${ }^{62}{ }^{63}$ More equal socioeconomic development ${ }^{61}$ and the improvement of the thermal standards of housing have both been demonstrated to be effective preventative interventions to curb excess deaths. ${ }^{60}$

Fuel poverty, the inability to heat the indoor environment to healthy levels, is likely to be a consequence of low income and poorly constructed housing. It is generally the poor who have to pay the most to keep warm in relation to income, but who are least able to improve the energy efficiency of their dwellings. Fuel poverty and keeping warm is a particular problem among the elderly population. ${ }^{5464}$

\section{HOUSEHOLD CROWDING}

Crowding in households refers to the number of people per room and is measured in a number of different ways, from simple measures of the number of people per bedroom to measures, such as the Canadian Overcrowding Index, with underlying normative expectations of social standards. ${ }^{65}$

Crowding has long been known to increase the risk of infectious diseases, such as meningoccocal disease, ${ }^{66}$ tuberculosis, ${ }^{67}$ and hepatitis $\mathrm{B}^{68}$ but it also has an impact on mental health ${ }^{69}$ and seems to be a contributor at an ecological level to premature mortality. ${ }^{70}$

\section{NOISE POLLUTION}

Excessive noise in overcrowded houses and from neighbouring houses and traffic is a common cause of sleep disruption, which can lead to impaired concentration and irritability. ${ }^{5}$

\section{MULTIPLE HOUSING DEPRIVATION}

Multiple housing deprivation refers to the experience of poor housing over the course of a lifetime. Poor housing conditions in infancy, childhood, and adulthood such as overcrowding and damp, cold dwellings, have a cumulative detrimental effect on physical and mental health. Multiple housing deprivation seems to pose health risks of similar proportions to smoking and, on average, greater than that posed by excessive alcohol consumption. ${ }^{72}$

Children seem to be particularly vulnerable to prolonged exposure to poor housing. ${ }^{73}{ }^{74} \mathrm{~A}$ number of adult diseases, such as Helicobacter pylori, have been traced back to exposure 
to crowding in childhood. ${ }^{75}$ Associations between poorer housing conditions in childhood and mortality from common diseases in adulthood are not strong, but are distinguishable from other aspects of social and economic deprivation. ${ }^{73}$

\section{HOUSING CONDITION SURVEYS}

A housing condition survey is a systematic survey of the physical condition of a dwelling, which identifies remediable hazards that otherwise have a negative impact on health and wellbeing. Houses are usually categorised according to fitness standards by environmental health officers or building inspectors so that local authorities can monitor and enforce regulatory standards to promote acceptable healthy housing. ${ }^{76}$ For example, the 1996 English House Condition Survey showed that that 1522000 UK dwellings did not meet the required fitness standards. ${ }^{77}$

\section{HOUSING TENURE}

Tenure is the legal conditions under which people live in their dwellings. Homes can be rented or owner occupied. If they are rented they can be rented from a private or public landlord. If homes are owner occupied, they may be owned with or without a mortgage, but, unlike rental properties, they can provide some financial benefits. One key advantage for many home buyers is that paying off a mortgage is a regular, "forced" form of saving, which yields security in later years.

Those who own their own home, with or without a mortgage, are likely to be in better health than those who rent their house, either from private or public landlords. There is a strong relation between rental housing tenure and higher death rates even within social classes. Several British studies have shown more variation in mortality between owners and tenants within occupational social class groups than between social classes within tenure classes. These relations are also related to self perceived health, rates of long term illness, and general practitioner consultation rates. ${ }^{78} 79$

While home ownership may generate a degree of security and control, particularly in countries where such behaviour is financially rewarded through tax assistance, it may not always be health promoting. Those households that fall behind on their mortgage payments may suffer increased insecurity and poorer mental health. ${ }^{80}$

\section{SOCIAL HOUSING}

Social housing is subsidised public sector housing that is provided to tenants by local, state, or national governments or not for profit trusts. Housing is usually allocated according to a social allocation formula that takes account of the prospective tenants' health and social circumstances. The rent may be determined as a proportion of the household income, in which case tenants are likely to have more disposable household income. Social housing can also be called affordable housing, council housing, or state housing. In some countries, housing subsidies are provided by welfare payments or vouchers as a way of offering those on low incomes greater choice of whether to rent privately or publicly, or become owner occupiers. ${ }^{81}$

The expansion of social housing as part of state welfare policies was thought to have weakened the link between housing and health. However, area effects remain whereby even in the same city, there are "good" and "bad" estates. In the good estates the health of the tenants is measurably better. ${ }^{82}{ }^{83}$ This may be the result of health selection, whereby the social allocation system filters people with poorer health into certain estates, or it may be that the reputation of certain areas means that people become less attached to these communities. This can lead to more residential mobility, which further weakens these areas' social structures and organisations. ${ }^{84}$ The recent sale of better quality social housing under neo-liberal governments may have reduced fiscal burdens, but has led in some countries to a further concentration of tenants with low incomes and poorer health in identifiably socioeconomically deprived areas. ${ }^{85}$

\section{SHELTERED HOUSING}

Sheltered housing is subsidised, social housing that is provided to tenants with serious, chronic health problems or disabilities. Those with chronic mental health problems are particularly vulnerable in the private rental housing market and have been shown to benefit from sheltered housing. ${ }^{86}$ Tenants are monitored by case workers and are provided with the necessary social supports and health services.

Half way housing is transitional sheltered housing that is provided by social agencies for people leaving closed institutions such as mental hospitals or prisons, who otherwise would be likely to face difficulties in budgeting to pay full housing costs, or may be discriminated against in the private rental housing market.

\section{HOUSING RELATED INJURIES}

Houses can have a number of potential hazards inside, such as stairwells and loose carpets, ${ }^{87} 88$ and outside such as driveways. ${ }^{89}$ Fires are a major cause of mortality, particularly among poorer people who because of their social and economic circumstances are more likely to smoke..$^{90-93}$

\section{HOUSING DISCRIMINATION}

Housing discrimination refers to the racism that some groups such as indigenous people, migrants, and ethnic minorities are more likely to suffer personally from private landlords if they are renting, and from institutional lenders if they are seeking a mortgage. ${ }^{94}{ }^{95}$ People from ethnic minorities with disability are more likely to suffer double discrimination. ${ }^{96}$

\section{HOUSING WEALTH}

Housing is the largest capital asset many families own and thus can be used to provide financial flexibility, for example, as collateral against a personal loan. Housing wealth is the net asset value of an owner occupied dwelling calculated as the market value, minus the mortgage debt. Housing costs are usually the largest item of household expenditure. To adjust for this, disposable income is sometimes calculated after housing costs have been accounted for. ${ }^{97}{ }^{98}$ When interest rates rise, households with mortgages can face a decline in after-housing disposable income.

Older people are more likely to have mortgage free homes, but may not have the income to maintain them. ${ }^{99}$ However, there are various reverse mortgage or equity schemes that are designed to enable older people to trade their equity in their house for regular income during their lifetime, although these have a high potential for coercion.

\section{HOUSING AS PSYCHOSOCIAL SPACE}

Housing is a private space with a public face, which can be seen as a symbolic extension of self. Housing is both a material asset and a psychosocial symbol of achieved status. It affects how people see themselves and are seen by others. ${ }^{100}$ Homes provide a secure space free from outside surveillance. ${ }^{101}$ Expectations and aspirations are conditioned by experience so that poor housing and deprived neighbourhoods may lead to pessimism, passivity, chronic stress, and a general state of dissatisfaction. ${ }^{102}$ If housing is of a relatively low standard, young people may want to distance themselves from the indoors and spend more time outside their home with their peers than with their families, which can dilute the impact of parenting, educational achievements, and the development of social norms. 


\section{IMPACTS OF HOUSING ON MENTAL HEALTH}

Housing has a moderately strong effect on the mental health of the occupants, particularly women, who through their child rearing roles spend more time at home on average than men. ${ }^{69}{ }^{103-108}$ Some designs of housing such as high rise housing often cause undue problems for older people and women, carrying shopping and small children, and make it more difficult for parents to supervise their children playing outside. ${ }^{109}$ There is also a perception that high rise apartments are less safe from crime ${ }^{110}$ and housing height is associated with decreased levels of mental health. ${ }^{111}$

There is a demonstrated cumulative impact of poor housing on mental health. For example, women in damp housing are more likely than men to experience emotional upsets because of overcrowding leading to disturbed sleep and on-going frustration from attempts to get repairs made, or failing that, rehousing, and in the meantime to keep the dwelling clean. ${ }^{112}$

\section{HOUSING INTERVENTIONS}

Housing is a readily available setting for a number of public health interventions, but there is a lack of research results from intervention studies alone to support improved housing as a robust means to improve health. ${ }^{113}{ }^{114}$ Insulating existing homes, providing effective safe heaters, and where necessary subsidised power, has been shown theoretically ${ }^{115}$ and in practice, to increase older people's health and wellbeing ${ }^{113}{ }^{116-121}$ and the health of children with asthma. ${ }^{122}$ In some cases the intervention prevented only further deterioration in health. ${ }^{120}$ The construction of new "passive" houses that are well insulated, have no active heating or cooling systems and use passive solar energy even in winter time, costs around 10\% more but reduces energy running costs by a factor of 10 over the building lifetime. ${ }^{123}$ Such sustainable housing can increase the disposable income of the households and help to reduce inequalities.

Housing renewal is often carried out on sub-standard housing in socioeconomically deprived neighbourhoods, although it is likely to be less discriminating than selecting individual houses through housing condition surveys. ${ }^{59}$ Several before and after studies have shown that the mental health of tenants has improved after housing renewal or community regeneration, ${ }^{103} 120124$ although some have reported adverse effects on general health after rehousing. ${ }^{106} 125$ Preliminary results of experimental relocation of families from areas of deprivation to improved housing in middle income areas have shown social and health gains ${ }^{126}$ and in another study, when the shift was to private housing, an improvement in mental health. ${ }^{127}$

\section{HOUSING NEIGHBOURHOODS}

The social and physical characteristics of the area surrounding houses are important for maintaining the good health of the occupants. Following the evidence that improving housing alone is insufficient to greatly improve the health of occupants, the focus has shifted to the health of the community and the local geographical neighbourhood. Neighbourhoods have a small but consistent impact on health status. ${ }^{128}$ Various omnibus measures of area based deprivation have been developed to rank the social and economic deprivation of neighbourhoods. Some are census based, some rely on municipal or school records. ${ }^{129} 130$ Some are based on systematic videotapes of street life and have been used to develop concepts such as collective efficacy and structural constraints in order to explore different neighbourhoods' shared expectations for the social control of public space. ${ }^{131}$ Systematic observational studies have also shown that both place and people, both the context and the composition of neighbourhoods, are important in determining health. ${ }^{132}$

Multilevel analyses using area based measures, and increasingly using geo-coding, have shown that neighbourhood effects have a small, but significant impact on mortality and premature mortality, ${ }^{133-136}$ self reported health status, ${ }^{137}$ diseases such as gonorrhoea, ${ }^{138}$ as well as being risk factors for morbidity such as low birth weight. ${ }^{139}$ Aspects of neighbourhoods that have been identified as having an impact on health are: the presence or absence of local amenities, such as parks and sports facilities; "incivilities" such as the presence of graffiti, boarded up houses, garbage accumulation, abandoned cars and broken windows, and the signalling effect of these physical features that no one cares $^{102}$; the perception of neighbourhoods as "safe" and under effective informal social controls ${ }^{100} 107110138$; and the number of local organisations. ${ }^{140} 141$

Others have postulated that neighbourhood conditions directly influence habits of privacy, child rearing, house keeping, and study, which can have an indirect effect on health. ${ }^{142}$

\section{HOUSING AND NEIGHBOURHOOD ATTACHMENT}

Families who live for a long time in a particular house can be categorised as attached to their house and local community and contributing to residential stability. Neighbourhood attachment is likely to have benefits for the health of the family and the stability of the neighbourhood. Neighbourhood stability in childhood is associated with better self reported health in mid-life, but as this stability is linked to family stability, the effects are difficult to disentangle. ${ }^{143}$

Residential stability refers to the social reproduction of neighbourhood residential structures, when typically population gains offset losses and home values appreciate. ${ }^{131}$ When longstanding families and households leave a neighbourhood, there is the possibility of destabilising social norms through the disruption of social networks. However, the destabilising effects of high levels of mobility are likely to have differential effects on different groups, depending on their social position and life stage and the material, social, and cultural resources from which they can draw. Many impoverished neighbourhoods have a high level of residential stability, yet poorer health. However, if the location, such as an inner city suburb becomes desirable and "gentrification" occurs, the in-migration of affluent households to poorer neighbourhoods can improve the health status of a neighbourhood simply through compositional changes.

Moving can be a normal part of family formation or a planned sign of upward mobility, but it can also reflect desperation and a downward spiral in health and welfare. ${ }^{144}$ This is one of the areas where qualitative research is able to illuminate the interaction between the increasing complexity of family life and residential mobility. ${ }^{145}$ The ability to move houses is related to the distribution of wealth and income in a population and the availability of social housing. Economic cycles and the local housing market are an integral part of this process. ${ }^{97}$

\section{FUTURE HOUSING RESEARCH DIRECTIONS}

Households, houses, and neighbourhoods are nested in such a way that the analytical tools of multilevel modelling can ideally illuminate their interrelation. However, the guidance of plausible theoretical models is an essential prerequisite for such analyses, if the field of housing and health research is to conceptually advance. Such models should progressively take account of the indoor built environment, as well as social and ethnic relations and the formal and informal rules that govern them. Both the direct and indirect effects of housing 
are also important, particularly the differential impact on age groups. The long term impacts of housing conditions need to be considered more in longitudinal studies.

Houses and neighbourhoods are a very practical setting for public health action and by their nature combine both private and public interests. Housing studies are more likely to attract broad public, policy and political support than most other settings. Housing policy interventions provide opportunities for natural experimental studies that can provide some fruitful answers to the key public health question of how we can reduce social and economic determinants of health inequalities. However, current interventions are limited by their scope and their narrow definitions of housing and health. It is hoped that this glossary highlights useful terms of reference, which will contribute to a broader environmental approach to improving health.

\section{ACKNOWLEDGEMENTS}

Comments by Ralph Chapman and the anonymous reviewers were much appreciated.

Funding: The Health Research Council of New Zealand funds the Housing and Health Research Programme.

Conflicts of interest: none declared

\section{REFERENCES}

1 Dickens C. A tale of two cities. Penguin Classics. London: Penguin Books, 2000 [1859]).

2 Myrdal G. An American dilemma. New York: Harper and Bros, 1944.

3 Chadwick E. General report on the sanitary conditions of the labouring population of Great Britain. London: W Clowes, 1842

4 Engels $\mathrm{F}$. The condition of the working class in England. London: Granada, 1969 [1845])

5 British Medical Association. Housing and health: building for the future. London: British Medical Association, 2003.

6 Acheson D. Independent inquiry into inequalities in health report. London: HMSO, 1998

7 Department of Health. Saving lives: our healthier nation. London: The Stationery Office, 1999.

8 National Health Committee. The social, cultural and economic determinants of health in New Zealand: action to improve health. Wellington: The National Advisory Committee on Health and Disability, 1998.

9 Anderson K. Epidemiological approach to indoor air problems. Indoor Air 1998;(suppl 4):32-9.

10 Alavanja MC, Lubin JH, Mahaffey JA, et al. Residential radon exposure and risk of lung cancer in Missouri. Am J Public Health 1999;89:42-8.

11 Gemmell I. Indoor heating, housing conditions, and health. J Epidemiol Community Health 2001:55:928-9.

12 Hasselblad V, Eddy DM, Kotchmar DJ. Synthesis of environmental evidence: nitrogen dioxide epidemiological studies. Journal of Air and Waste Management Association 1992:42:662-71.

13 Melia RJW, Florey CdV, Altman DG, et al. Association between gas cooking and respiratory disease in children. BMJ 1977;2:149-52.

14 Melia RJW, Florey CdV, Morris RW, et al. Childhood respiratory illness and the home environment II. Association between respiratory illness and nitrogen dioxide, temperature and relative humidity. Int J Epidemio 1982;11:164-9.

15 Brunekreef $B$, Janssen NAH, de Hertog J, et al. Indoor nitrogen dioxide exposure and children's pulmonary function. Journal of Air and Waste Management Association 1990:40:1252-6.

16 Chauhan AJ, Inskip HM, Linkaker CH, et al. Personal exposure to nitrogen dioxide $\left(\mathrm{NO}_{2}\right)$ and the severity of virus-induced asthma in children. Lancet 2003;361:1939-44.

17 Sargent JD, Brown MJ, Freeman JL. Childhood lead poisoning in Massachusetts communities: its association with socioedemographic and housing characteristics. Am J Public Health 1985;85:528-34.

18 Warren C. Brush with death: a social history of lead paint. Baltimore: John Hopkins University, 2000

19 Bellinger D, Leviton A, Waternaux $C$, et al. Low-level lead exposure, social class and infant development. Neurotoxicol Teratol 1993;10:497-503.

20 Sharfstein J, Sandel M, Kahn RS, et al. Is child health at risk while families wait for housing vouchers? Am J Public Health 2001;91:1191-2.

21 Needleman H, Gatsonis C. Low level lead exopsure and the IQ of children. JAMA 1990;263:673-8.

22 Sargent JD, Dalton $M$, Demidenko $E$, et al. The association between state housing policy and lead poisoning in children. Am J Public Health 1999:89:1690-5.

23 Ryan D, Levy B, Pollack S, et al. Protecting children from lead poisoning and building healthy communities. Am J Public Health 1999;89:822-4.

24 Cuijpers CEJ, Swaen GMH, Wesseling G, et al. Adverse effects of the indoor environment on respiratory health in primary school children. Environmental Research 1994;68:11-23.
25 Peat JK, Dickerson J, Li J. Effects of damp and cold on respiratory health. Allergy 1998;53:120-8.

26 Platt SD, Martin CJ, Hunt SM, et al. Damp housing, mould growth, and symptomatic health state. BMJ 1989;298:1673-8.

27 Spengler J, Neas L, Nakai S, et al. Respiratory problems and housing characteristics. Indoor Air 1994;4:72-82.

28 Dales RE, Zwanenburg H, Burnett $R$, et al. Respiratory health effects of home dampness and moulds among Canadian children. Am J Epidemio 1991; 134:196-203.

29 Haverinen U, Husman T, Pekkanen i, et al. Characteristics of moisture damage in houses and their association with self-reported symptoms of the occupants. Indoor Built Environment 2001;10:83-94.

30 Brunekreef B. Damp housing and adult respiratory symptoms. Allergy 1992:47:498-502.

31 Brunekreef B, Dockery D, Speizer F, et al. Home dampness and respiratory morbidity in children. Americn Review of Respiratory Disease 1989:140:1363-7.

32 Dales RE, Burned R, Zwanenburg H. Adverse health effects among adults exposed to home dampness and moulds. American Review of Respiratory Disease 1991; 143:505-9.

33 Zock J-P, Jarvis D, Luczynska C, et al. Housing characteristics reported mould exposure, and asthma in the European Community. J Allergy Clin Immunol 2002:110:285-92.

34 Koskinen OM, Husman TM, Meklin T, et al. The relationship between moisture or mould observations in houses and the state of health of their occupants. Eur Respir J 1999;14:1363-7.

35 Koskinen OM, Husman TM, Hyvarinen AM, et al. Two moldy day-care centres: a follow-up study of respiratory symptoms and infections. Indoor Air 1997;7:262-8

36 Strachan P. Dampness, mould and respiratory disease in children. In: Burridge R, Ormandy D, eds. Unhealthy housing. London: Chapman and Hall, 1993:94-116.

37 Holst PE, Coleman ED, Sherridan JE, et al. Asthma and fungi in the home. N Z Med J 1983;96:718-20.

38 Kleiner K. Deadly damp. New Scientist 1997:10.

39 Samson RA, Flannigan B, Flannigan ME, et al. Health indicators of fungi in indoor environments. Air Quality Monographs. Amsterdam: Elsevier, 1994

40 Tobin R, Baranowski E, Gilman A, et al. The significance of fungi in indoor air: report of a working group. Can J Public Health 1987;78:51-3.

41 Flappan SM, Portnoy J, Jones P, et al. Infant pulmonary hemorrhage in a suburban home with water damage and mold (Strachybotrys atra). Environ Health Perspect 1999; 107:927-30.

42 Hunt S. Damp and mouldy housing: a holistic approach. In: Burridge R, Ormandy D, eds. Unhealthy housing. London: Chapman and Hall, 1993:69-93.

43 Hyndman SJ. Housing dampness and health amongst British Bengalis in East London. Soc Sci Med 1990;30:131-41

44 Rylander R. Microbial cell wall contaminants in indoor air and their relation to disease. Indoor Air 1998;(suppl 4):59-65.

45 Verhoeff AP, Burge HA. Health risk assessment of fungi in home environments. Ann Allergy Asthma Immunol 1997;78:544-54.

46 Dornelas de Andrade A, Birnbaum J, Lanteaume A, et al. Housing and house-dust mites. Allergy 1995;30:142-6.

47 Iversen $M$, Dahl R. Allergy to storage mites in asthmatic patients and its relation to damp housing conditions. Allergy 1990;45:81-5.

48 Wickens K, Pearce N, Siebers R, et al. Indoor environment, atopy and the risk of asthma in New Zealand children. Pediatr Allergy Immunol 1999:10:199-208.

49 Collins K. Cold- and heat-related illnesses in the indoor environment. In: Burridge R, Ormandy D, eds. Unhealthy housing. London: Chapman and Hall, 1993:117-40.

50 Donaldson GC, Keatinge WR. Excess winter mortality:influenza or cold stress? Observational study. BMJ 2002;324:89-90.

51 Evans J, Hyndman S, Stewart-Brown S, et al. An epidemiological study of the relative importance of damp housing in relation to adult health. $J$ Epidemiol Community Health 2000;54:677-86.

52 Markus TA. Cold, condensation and household poverty. In: Burridge R, Ormandy D, eds. Unhealthy housing. London: Chapman and Hall, 1993:141-67

53 Lloyd EL. Hypothesis: temperature recommendations for elderly people: Are we wrong? Age Ageing 1990;19:264-7.

54 Macey SM. Hypothermia and energy conservation: a tradeoff for elderly persons? Int J Aging Hum Dev 1989;29:151-61.

55 Morgan R, Blair A, King D. A winter survey of domestic heating among elderly patients. J $R$ Soc Med 1996;89:85-6.

56 The Eurowinter Group. Cold exposure and winter mortality from ischaemic heart disease, cerebrovascuar disease, respiratory disease, and all cases in warm and cold regions of Europe. Lancet 1997;349:1341-6.

57 Curwen M. Excess winter mortality: A British phenomenon? Health Trends, 1990/91, 22:169-75

58 Isaacs N, Donn M. Health and housing-seasonality in New Zealand mortality. Austr J Public Health 1993;17:68-70.

59 Aylin P, Morris S, Wakefield J, et al. Temperature, housing, deprivation and their relationship to excess winter mortality in Great Britain, 1986-1996. Int J Epidemiol 2001:30:1100-8.

60 Healy JD. Excess winter mortality in Europe: a cross country analysis identifying key risk factors. J Epidemiol Community Health 2003;57:784-9.

61 Kunst AE, Looman CWN, Mackenbach JP. The decline in winter excess mortality in the Netherlands. Int J Epidemiol 1990;20:971-7.

62 Blane D, Mitchell R, Bartley M. The "inverse housing law" and respiratory health. J Epidemiol Community Health 2000;54:754-9. 
63 Mitchell R, Blane D, Bartley M. Elevated risk of high blood pressure: climate and the inverse housing law. Int J Epidemiol 2002;31:831-8.

64 Howden-Chapman P, Signal L, Crane J. Housing and health in older people; ageing in place. Social Policy Journal of New Zealand 1999;13:14-30.

65 Canada Mortgage and Housing Corporation. Core housing need in Canada. Ottawa: Canadian Government Print, 1991.

66 Baker M, McNicholas A, Garrett N, et al. Household crowding a major risk factor for meningococcal disease in Auckland children. Pediatr Infect Dis J 2000; 19:983-90.

67 Coetzee N, Yach D, Joubert G. Crowding and alcohol abuse as risk factors for tuberculosis in the Mamre population. S Afr Med J 1988;74:352-4.

68 Milne A, Allwood G, Moyes C, et al. A seroepidemiological study of the prevalence of hepatitis $B$ infection in a hyperendemic New Zealand community. Int J Epidemiol 1987; 16:84-90.

69 Entner Wright BR, Caspi A, Moffit TE, et al. Factors associated with doubledup housing-a common precursor to homelessness. Social Service Review 1998;72:92-111.

70 Kellett JM. Crowding and mortality in London boroughs. In: Burridge R, Ormandy D, eds. Unhealthy housing. London: Chapman and Hall, 1993:209-22.

71 Lowry S. Noise, space, and light. BMJ 1989;299:1439-42.

72 Marsh A, Gordon D, Pantazis C, et al. Home sweet home? The impact of poor housing on health. London: Policy Press, 1999

73 Dedman DJ, Gunnell D, Davey Smith G, et al. Childhood housing conditions and later mortality in the Boyd Orr cohort. J Epidemiol Community Health 2001;55:10-15.

74 Wilner DN, Price-Walkley R, Schram JM, et al. The effects of housing quality on morbidity: preliminary findings of the John Hopkins longitudinal study. Am J Public Health 1960;50:55-63.

75 Mendall MA, Goggin PM, Molineaux N, et al. Childhood living conditions and Heliocobacter pylori seropositivity in adult life. Lancet 1992;339:896-7.

76 Scottish Office. Poor housing and ill health: a summary of research evidence. Edinburgh: Central Research Office, 1998.

77 Department of the Environment Transport and the Regions. English house conditions survey. London: HMSO, 2000

78 Macintyre S, Ellaway A, Der G, et al. Do housing tenure and car access predict health because they are simply markers of income or self esteem? A Scottish study. J Epidemiol Community Health 1998;52:657-64.

79 Macintyre S, Hiscock R, Kearns A, et al. Housing tenure and car access: further exploration of the nature of their relations with health in a UK setting. $J$ Epidemiol Community Health 2001;55:330-1.

80 Nettleton S, Burrows R. Mortgage debt, insecure ownership and health: an exploratory analysis. Sociology of Health and Illness 1998;20:731-53.

81 Ong P. Subsidized housing and work among welfare recipients. Housing Policy Debate 1998;9:775-94.

82 Byrne D, Keithley J. Housing and the health of the community. In: Burridge R, Ormandy D, eds. Unhealthy housing. London: Chapman and Hall, 1993:41-66.

83 Blackman T, Evason E, Melaugh M, et al. Housing and health: a case study of two areas in West Belfast. Journal of Social Policy 1989;18:1-26.

84 Smith SJ, Mallinson S. The problem with social housing: discretion, accountability and the welfare ideal. Policy and Politics 2001;24:339-57.

85 Murphy L, Kearns RA. Housing New Zealand Ltd: privatisation by stealth. Environment and Planning 1994;26:623-37.

86 Newman S. Housing attributes and serious mental illness: implications for research and practice. Psychiatr Serv 2000;52:1309-16.

87 Britten RH, Brown JE, Altman I. Certain characteristics of urban housing and their relation to illness and accidents: summary of findings of the national health survey. Milbank Memorial Fund Q 1940;18:19-113.

88 Ransom R. Accidents at home: the modern epidemic. In: Burridge R, Ormandy D, eds. Unhealthy housing. London: Chapman and Hall, 1993:223-55

89 Roberts I, Norton R, Jackson R. Driveway-related child pedestrian injuries: a case-control study. Pediatrics 1995;95:405-8.

90 DiGuiseppi C, Roberts I, Li L. Smoke alarm ownership and house fire death rates in children. J Epidemiol Community Health 1998;52:760-1.

91 Istre GR, McCoy MA, Osborn L, et al. Deaths and injuries from house fires. N Engl J Med 2001;344:1911-16.

92 Roberts I. Deaths of children in house fires: Fanning the flames of child health advocacy? BMJ 1995;311:1381-2.

93 Runyan CW, Bangdiwala SI, Linzer MA, et al. Risk factors for fatal residential fires. N Engl J Med 1992;327:859-63.

94 Bianchi SM, Farley R, Spain D. Racial inequalities in housing: an examination of recent trends. Demography 1982;19:37-51.

95 Charsley K, Lambert H, Davey Smith G. Housing tenure, ethnicity and inequalities: towards a contextualised approach. Health Variations 1999;3:6-9.

96 Harrison M, Davis C, ed. Housing, social policy and difference: disability, ethnicity, gender and housing. Bristol: The Policy Press, 2001.

97 Dorling D, Shaw M, Brimblecome N. Housing wealth and community health: exploring the role of migration. In: Graham $\mathrm{H}$, ed. Understanding health inequalities. Buckingham: Open University Press, 2001:186-99.

98 Ellaway A, Macintyre S. Does housing tenure predict health in the UK because it exposes people to different levels of housing related hazards in the home or its surroundings? Health and Place 1998:4:141-50.

99 Reschovsky JD, Newman SJ. Home upkeep and housing quality of older homeowners. J Gerontol 1991;46:288-97.

100 Dunn JR. Housing and inequalities in health: a study of socioeconomic dimensions of housing and self reported health from a survey of Vancouver residents. J Epidemiol Community Health 2002;56:671-82.
101 Dupuis A, Thorns DC. Home, home ownership and the search for ontological security. The Sociological Review 1998;46:24-47.

102 Cohen D, Spear S, Scribner R, et al. "Broken windows" and the risk of gonorrhea. Am J Public Health 2000;90:230-6.

103 Wilner DM, Walkley RP, Schram JM, et al. Housing as an environmental factor in mental health: the John Hopkins Longitudinal Study. Am J Public Health 1960;9:55-63.

104 Gabe J, Williams P. Is space bad for your health? The relationship between crowding in the home and emotional distress in women. Sociology of Health and IIIness 1986;8:351-71.

105 Heenan D, Gray AM. Women, public housing and inequality: a Northern Ireland perspective. Housing Studies 1997; 12:157-71.

106 Smith CA, Smith CJ, Kearns RA, et al. Housing stressors, social support and psychological distress. Soc Sci Med 1993;37:603-12.

107 Halpern D. Mental health and the built environment. More than bricks and mortar? London: Taylor and Francis, 1995:237.

108 Hopton JL, Hunt SM. Housing conditions and mental health in a disadvantaged area in Scotland. J Epidemiol Community Health 1996;50:56-61.

109 Freeman H. Mental health and high-rise housing. In: Burridge R, Ormandy D, eds. Unhealthy housing. London: Chapman and Hall, 1993:168-90.

110 Green G, Gilbertosn JM, Grimsley MFJ. Fear of crime and health in residential tower blocks: a case study in Liverpool, UK. European Journal of Public Health 2002;12:10-15.

111 Evans GW, Wells NM, Moch A. Housing and mental health: a review of the evidence and a methodological and conceptual critique. New York: Department of Agriculture, 2000:1-26.

112 Gabe J, Williams P. Women, crowding and mental health. In: Burridge R, Ormandy D, eds. Unhealthy housing. London: Chapman and Hall, 1993:191-208.

113 Thomson H, Petticrew M, Morrison D. Health effects of housing improvement: systematic review of intervention studies. BMJ 2001;323:187-90.

114 Saegert SC, Kllitzman S, Freudenberg N, et al. Healthy housing: a structured review of published evaluations of US interventions to improve health by modifying housing in the United states, 1990-2001. Am J Public Health 2003;93:1471-551.

115 Levy JI, Nishioka Y, Spengler JD. The public health benefits of insulation retrofits in existing houses in the United States. Environmental Health: A Global access Science Source 2003;2:http://www.ehjournal.net/ content $/ 2 / 1 / 4$

116 Keatinge WR, Coleshaw SRK, Holmes J. Changes in seasonal mortalities with improvement in home heating in England and Wales from 1964 to 1984. Int J Biometerol 1989;33:71-6.

117 Keatinge WR. Seasonal mortality among elderly people with unrestricted home heating. BMJ 1986;323:293.

118 Keatinge WR, Donaldson GC, Bucher K, et al. Cold exposure and mortality from ischemic heart disease, cerebrovascular disease, respiratory disease, and all causes in warm and cold regions of Europe. Lancet 1997;349:1341-6.

119 Heckman JR, Smith J. Assessing the case for social experiments. Journal of Economic Perspectives 1995;9:85-110.

120 Hopton JL, Hunt SM. The health effects of improvements to housing: a longitudinal study. Housing Studies 1996;11:271-86.

121 Thomson $\mathbf{H}$, Pettigrew M, Douglas $M$. Health impact assessment of housing improvements: incorporating research evidence. J Epidemiol Community Health 2003;57:11-16.

122 Somerville M, Mackenzie I, Owen P, et al. Housing and health: does installing heating in their home improve the health of children with asthma? Public Health 2000; 114:434-40

123 Hennicke $\mathbf{P}$, ed. Factor 4: a strategy for eco-efficiency. International symposium on business and the environment, Hyogo, Japan, 2000. Institute for Global Environmental Strategies.

124 Smith SJ, Alexander A, Easterlow D. Rehousing as a health intervention: miracle or mirage? Health and Place 1997;11:271-86.

125 Blackman T, Harvey J. Housing renewal and mental health: a case study. J Mental Health 2001;10:571-83.

126 Katz LF, Kling JR, Liebman JB. Moving to opportunity in Boston: early results of a randomised mobility experiment. The Quarterly Journal of Economics $2001 ; 116: 607-54$.

127 Leventhal T, Brooks-Gunn J. Moving to opportunity: an experimental study of neighbourhood effects on mental health. Am J Public Health 2003;93:1576-82.

128 Pickett KE, Pearl M. Multilevel analyses of neighbourhood socioeconomic context and health outcomes: a critical review. J Epidemiol Community Health 2001;55:111-22.

129 Townsend P, Phillimore P, Beattie A. Health and deprivation: inequality and the north. London: Routledge, 1988.

130 Salmond C, Crampton P, Sutton F. NZDep91. Aust N Z J Public Health 1998;22:835-7.

131 Sampson RJ, Raudenbush SW. Systematic social observation of public spaces: a new look at disorder in urban neighborhoods. American Journal of Sociology 1999;105:603-51

132 Maclntyre S, Maclver S, Sooman A. Area, class and health: should we be focussing on places or people? Journal of Social Policy 1993;22:213-34.

133 Diez Roux A, Stein Merkin S, Arnett D, et al. Neighborhood of residence and incidence of coronary heart disease. N Engl J Med 2001;345:99-106.

134 Martikainen P, Kauppinen TM, Valkonen T. Effects of the characteristics of neighbourhoods and the characteristics of people on cause specific mortality: a register based follow up study of 252000 men. J Epidemiol Community Health 2003;57:210-17. 
135 Cohen DA, Mason K, Bedimo A, et al. Neighbourhood physical conditions and health. Am J Public Health 2003;93:467-71.

136 Bosma H, Mheen vdHD, Borsboom GJJM, et al. Neighbourhood socioeconomic status and all-cause mortality. Am J Epidemiol 2001:153:363-71.

137 Malmstrom M, Sundquist J, Johansson SE. Neighborhood environment and self-reported health status: A multilevel analysis. Am J Public Health 1999:89:1181-6.

138 Sampson RJ, Raudenbush SW, Earls F. Neighbourhoods and violent crime: a multilevel study of collective efficacy. Science 1997;277:918-24.

139 Kreiger N, Chen TT, Waterman PD, et al. Choosing area based socioeconomic measures to monitor social inequalities in low birth weight and childhood lead poisonong: The Public Health Disparities Geocoding Project (US). J Epidemiol Community Health 2003;2003:186-99.
140 Kawachi I, Kennedy BP, Wilkinson RG. Crime: social disorganization and relative deprivation. Soc Sci Med 1999;48:719-31.

141 Kawachi I, Kennedy BP, Lochner K, et al. Social capital, income inequality, and mortality. Am J Public Health 1997:87:1491-8.

142 Schorr AL. Housing and its effects. In: Gutman R, Popenoe D, eds. Neighbourhood, city and metropolis: an integrated reader in urban sociology. New York: Random House, 1970:709-29.

143 Bures RM. Childhood residential stability and health at midlife. Am J Public Health 2003:93:1144-8.

144 Kearns RA, Smith CJ. The residential mobility experiences of marginalised populations. Tijdshcrift voor Economische en Sociale Geographie 1994;85:11-129.

145 Winstanley A, Thorns DC, Perkins HC. Moving house, creating home: exploring residential mobility. Housing Studies 2002;17:813-32.

\section{THE JECH GALLERY}

\section{Slum improvement needs community organisation}

n improved slums in today's India, fortunate communities have safe water supplies and metalled pathways or roads. But unless there is effective community organisation in the form of neighbourhood committees and the like, the basis for community governance and control, the danger is of a dependency culture. Where this occurs, broken water pumps go unmended and refuse uncollected. Public health is centrally about empowerment.

J R Ashton

North West Public Health Team, Department of Health, 18th Floor, Sunley Tower, Piccadilly Plaza, Manchester M1 4BE, UK johnrashton@blueyonder.co.uk

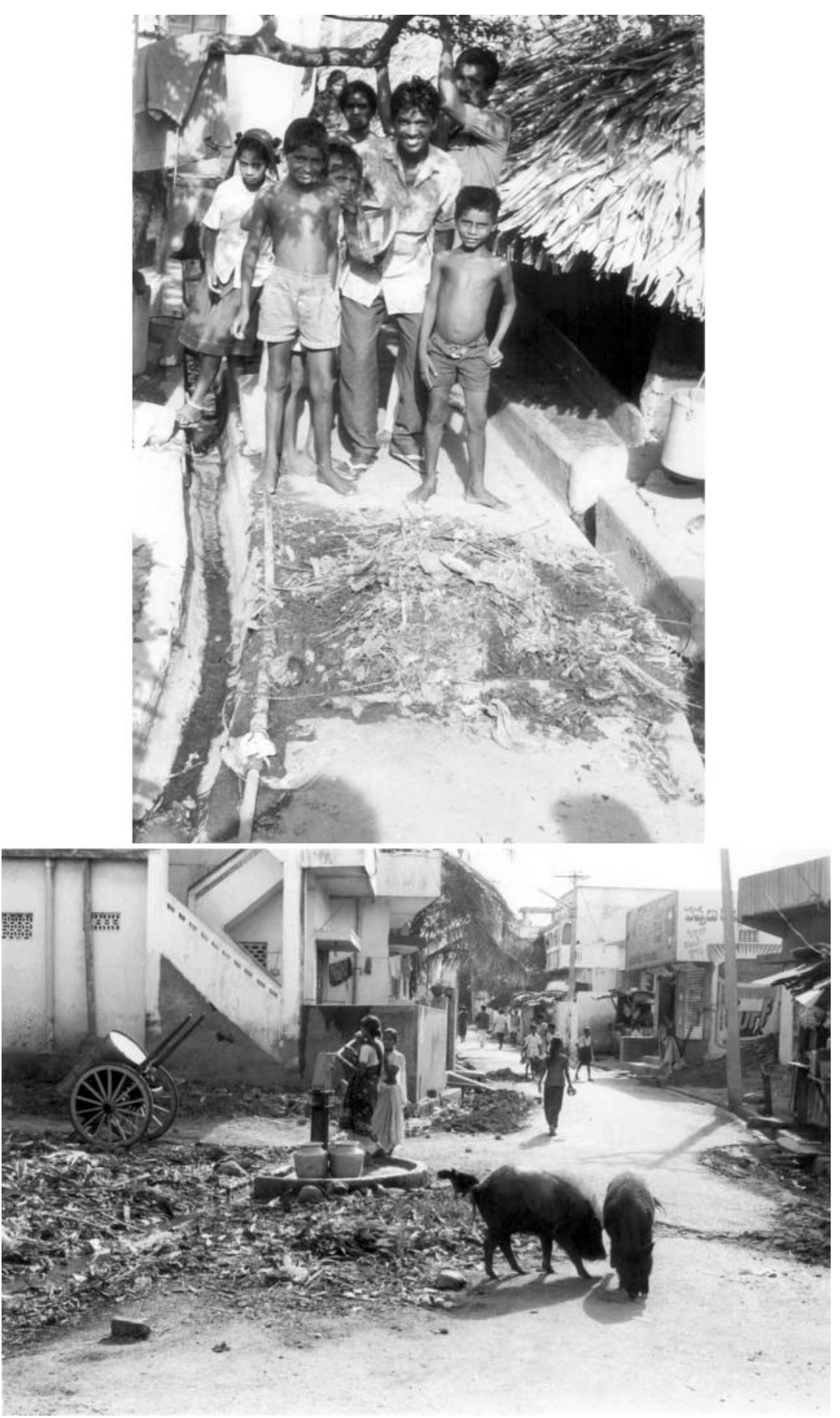

